Psychopharmacologia (Berl.) 25, 162-168 (1972)

(C) by Springer-Verlag 1972

\title{
Clonidine Induced Intrahypothalamic Stimulation of Eating in Rats
}

\author{
C. Brofikgamp and J. M. van Rossum \\ Department of Pharmacology, Catholic University Medical School \\ Nijmegen, The Netherlands
}

Received January 27, 1972 
Abstract. Intracerebral injection of $1 \mu l$ volumes of solutions containing noradrenaline, clonidine, oxymetazoline and phentolamine were performed in the antero-lateral hypothalamus of the Wistar rat at the level of the pars infracommissuralis of the Stria terminalis.

Intrahypothalamic clonidine in a dose as low as $1 \mathrm{\mu g}$ strongly increased food intake in satiated rats.

Clonidine $(4 \mu \mathrm{g})$ was more potent than noradrenaline $(12 \mu \mathrm{g})$ but as potent as oxymetazoline $(1.5 \mu \mathrm{g})$.

The clonidine induced eating response was completely blocked by the $\alpha$-sympatholytic drug phentolamine.

The results emphasize the role of clonidine as an activator of noradrenaline receptors in the central nervous system.

Key words: Noradrenaline - Clonidine - Adrenergic Imidazolines - Central Noradrenaline Receptors - Intracerebral Injections - Hypothalamic Eating System.

\section{Introduction}

There is considerable evidence that the adrenergic imidazolines such as naphazoline, oxymetazoline and xylometazoline are direct $\alpha$-receptor activators (Mujic and van Rossum, 1965). The recent antihypertensive agent, clonidine, an analogue of the adrenergic stimulant imidazolines, likewise shows peripheral $\alpha$-sympathomimetic effects (Boissier et al., 1968; Kobinger, 1967).

Several reports provide evidence for a central mechanism of action of clonidine (Shaw et al., 1971; Schmidt et al., 1969; Sherman et al., 1968) and $\alpha$-adrenergic blocking agents inhibit these actions of clonidine (Schmidt et al., 1970 and 1971). However, clonidine has not yet been administered directly into the central nervous system.

Adrenergic stimulants increase eating in satiated animals when introduced directly in the lateral hypothalamus (Grossman, 1962). By using selective $\alpha$ - and $\beta$-adrenergic stimulants as well as selective antagonists it was shown that noradrenergic receptor activation is 
the cause of intrahypothalamic noradrenaline facilitated eating (Slangen and Miller, 1969).

Since chemical stimulation of eating in the lateral hypothalamus is a clean model for central $\alpha$-adrenergic drug-receptor interaction, we used this model to study the central effects of clonidine and oxymetazoline.

\section{Methods and Materials \\ Stereotaxic Operations}

Cannulae with an outer diameter of $0.8 \mathrm{~mm}$ were implanted under stereotaxic conditions in the antero-lateral hypothalamus of male rats $(250-300 \mathrm{~g})$ under pentothal $(50 \mathrm{mg} / \mathrm{kg})$ anaesthesia. The tip of the cannula was placed in a position anterior 7.6, lateral 1.4 and deep -2.4, according to the atlas of König and Klippel (1963). The cannulae were fixed to the skull with dental cement, and a circular wall of cement was applied to the extending part of the cannula. The ring so formed was filled with latex (Rhodorsil ${ }^{\circledR}$ ) in order to fixate the plug of the cannula, and prevent the rat from scratching the cannula after recovery from surgery.

\section{Intrahypothalamic Injection}

The chemicals were dissolved in saline. The freshly prepared solutions were injected with a Hamilton syringe with an adjustable screw on the needle such that the solution could be deposited some distance (e.g. $0.5 \mathrm{~mm}$ ) beyond the tip of the cannula. By this procedure local destruction of brain tissue could be minimized. 8 consecutive injections were made in the same rat over a period of 3 weeks (see Table 1). The site of injection was controlled at the end of the experiment (Fig. 1). In six out of seven rats, the position of the cannula was correct.

The actual site of injection was established histologically. The average position of the injection site corresponded to anterior 6.25, lateral 1.2 and depth -2.0. This implied that the chemicals were deposited around the pars infracommissuralis of the Stria terminalis.

\section{Chemicals}

(-)Noradrenaline $(40 \mathrm{nmol}=12.7 \mu \mathrm{g}$ of hydrogen tartrate) was used as a reference drug. Clonidine was used initially in a dose of $200 \mathrm{nmol}(=53.3 \mu \mathrm{g}$ of $\mathrm{HCl}$ salt $)$ but later reduced to $50 \mathrm{nmol}$ $(=13.3 \mu \mathrm{g}) ; 15 \mathrm{nmol}(=4 \mu \mathrm{g})$ and $3.84 \mathrm{nmol}(=1 \mu \mathrm{g})$. Oxymetazoline was used in a dose of $5 \mathrm{nmol}(=1.5 \mu \mathrm{g})$. The alpha-sympatholytic 


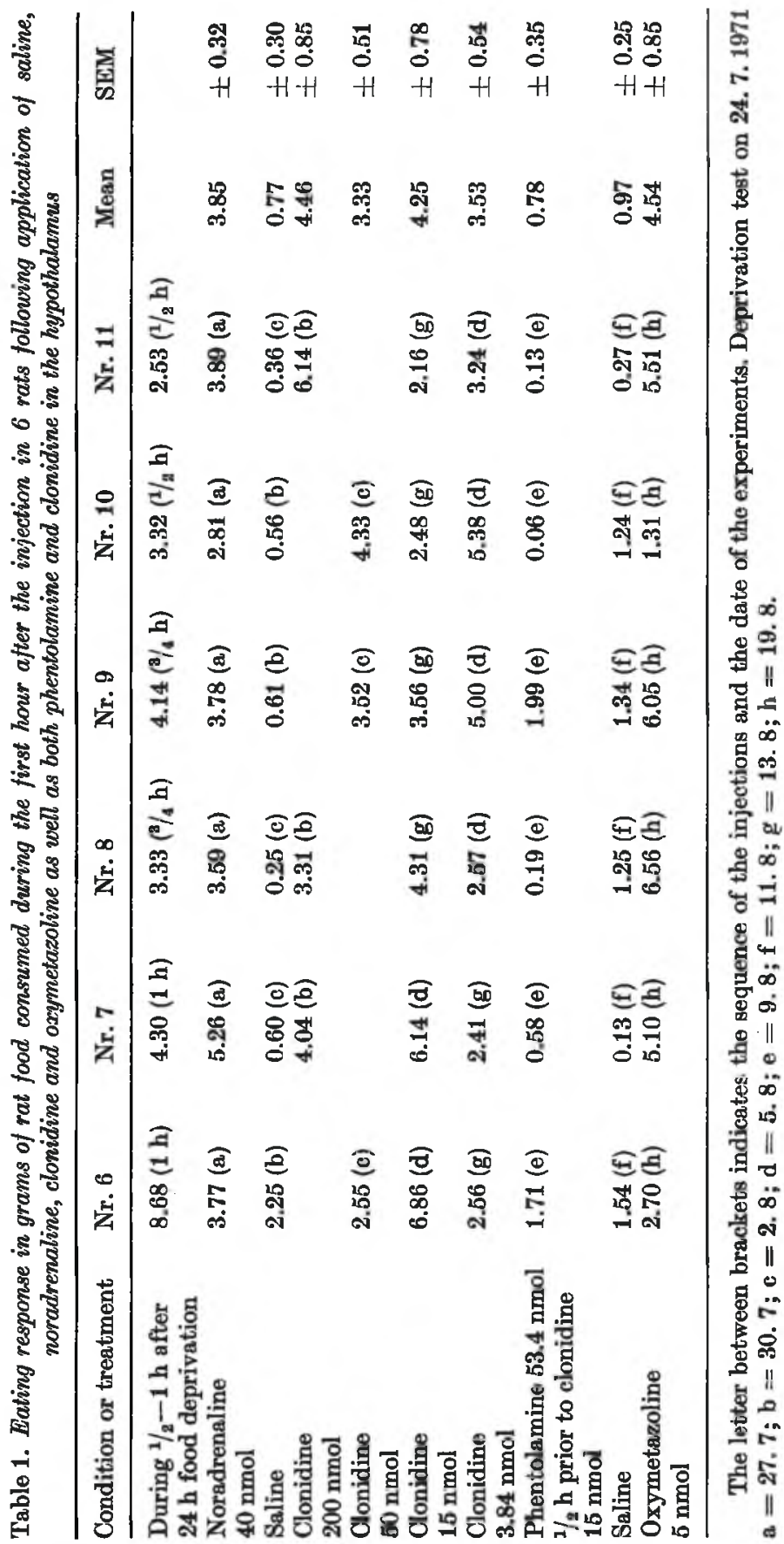



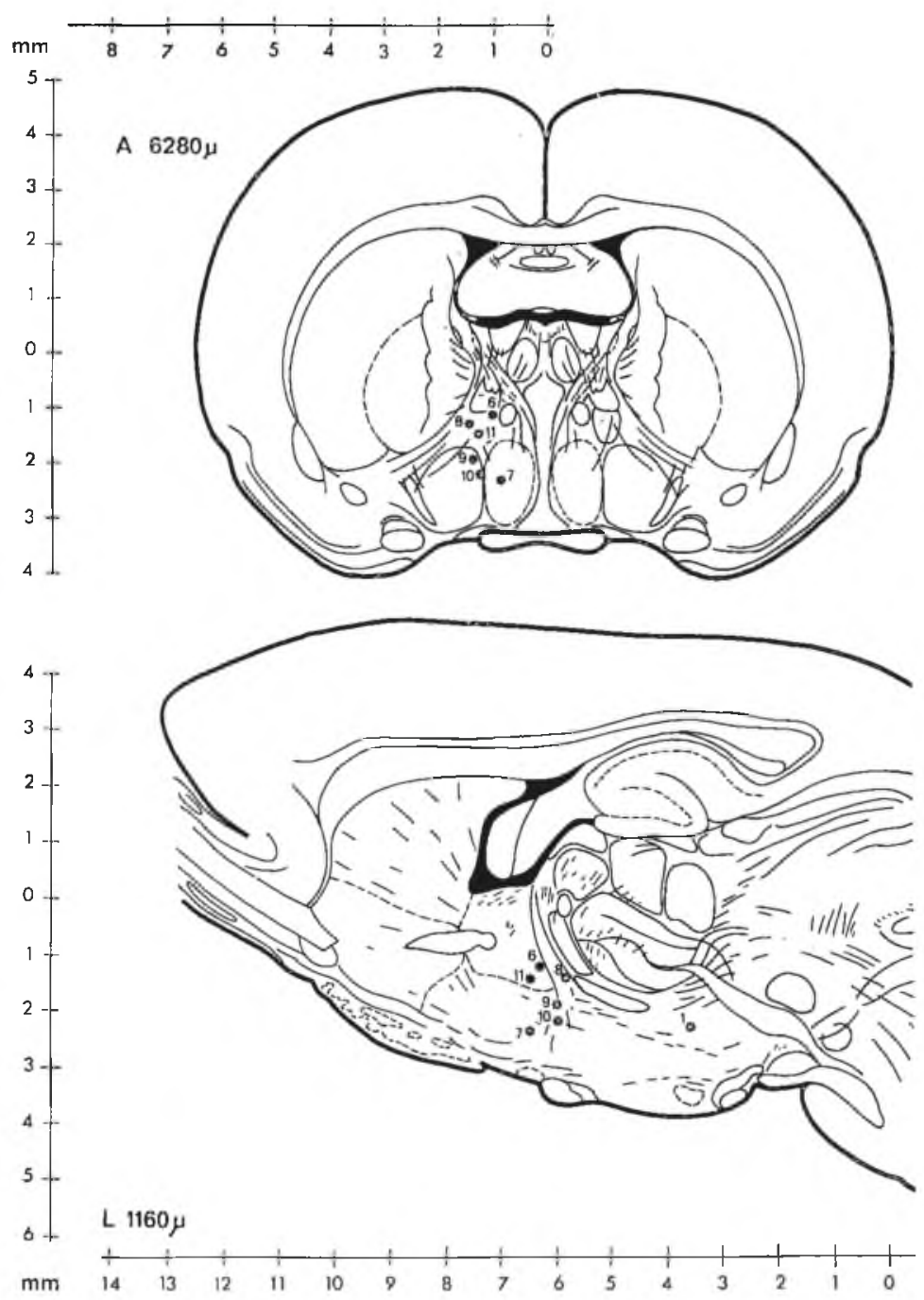

Fig.1. a Frontal section of the rat brain according to the atlas of König and Klippel in which the sites of application of the chemicals have been indicated. The numbers refer to the different rats. $b$ Sagital section of the rat brain in which the sites of injection have been indicated. In all rats except number 1, the position of the cannula appeared to be correct. For results of the various experiments see Table 1

drug phentolamine was used in a dose of $53 \mathrm{nmol}(=15 \mu \mathrm{g})$ one half hour prior to $15 \mathrm{nmol}$ clonidine. All doses or combinations were applied 6 times except for the initial experiments. 


\section{Eating Response}

The experiments were carried out in normal rat cages, by measuring the food intake in the first hour after intrahypothalamic injection. The rats were habituated to the cage by placing them in the test cage 5 times during one hour periods prior to the experiments, the last time after $24 \mathrm{~h}$ of food deprivation. During the experiments the rats had free access to food.

\section{Results}

From the 24 $\mathrm{h}$ food deprivation test it appeared that the rats were accustomed to the test cage since they consumed about $3 \mathrm{~g}$ in half an hour (Table 1).

The effects of the various intrahypothalamic injections in the individual rats are given in Table 1, together with the sequence of injections in each rat. Injection of the reference substance levonoradrenaline was effective in six of seven rats, causing an average food intake of $3.8 \mathrm{~g}$, whereas the food consumption following a saline injection amounted to about $0.8 \mathrm{~g}$ (Table 1 ). In one rat noradrenaline only induced a food consumption of $1.5 \mathrm{~g}$. Injections deeper in the hypothalamus were no more effective so that this rat was excluded

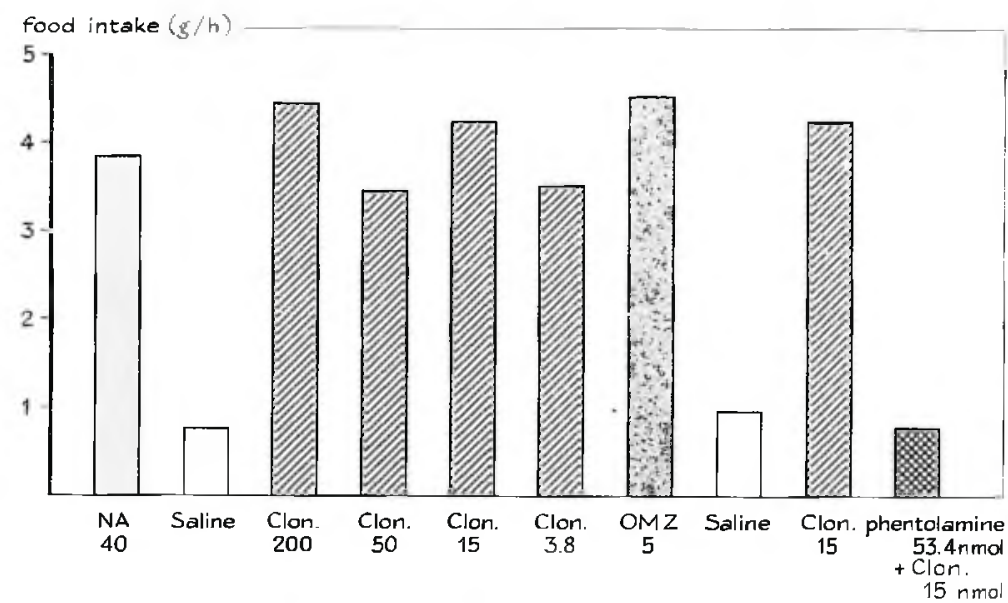

Fig. 2. Mean food intake in 6 satiated rats with cannulae in the correct position following intrahypothalamic injection of saline, noradrenaline, oxymetazoline and clonidine. The alphasympathomimetic drugs elicit a strong increase in food intake, while the alphasympatholytic phentolamine completely abolishes the effect of an adequate dose of clonidine 
from further experiments. From the histological control it appeared that in this rat the site of injection was too far posterior (Fig. 1).

Clonidine induced a strong eating response in all doses from 200-15 nmol (Fig.2), and even $4 \mathrm{nmol}$ was fully effective. It may be concluded that intrahypothalamically injected clonidine is more potent than noradrenaline, since $5 \mathrm{nmol}$ of the latter given under similar conditions is ineffective (Slangen, 1970).

The adrenergic imidazoline, oxymetazoline also strongly increased eating in a dose of $5 \mathrm{nmol}$, and it is therefore likewise more potent than noradrenaline.

Intrahypothalamically stimulatedeating by clonidine is completely blocked by the $\alpha$-adrenergic blocking agent phentolamine, when injected at the same site in the hypothalamus, half an hour prior to clonidine. It may therefore be concluded that clonidine acts by activation of noradrenaline receptors in the hypothalamus.

The sites of injection cluster around the pars infracommisuralis of the Stria terminalis. See Fig. 1.

\section{Discussion}

During the onehour period following intrahypothalamic injection, clonidine induces a greater food consumption than noradrenaline. This may however be due to a greater stability of clonidine over noradrenaline, rather than to a greater intrinsic potency. Clonidine differs from oxymetazoline only with respect to its high lipophylicity. This explains why clonidine easily passes the bloodbrain-barrier whereas oxymetazoline does not reach the brain in adequate amounts following systemic injection.

Clonidine also exerts local anaesthetic properties equal to procaine (Hoefke and Kobinger, 1966). Clonidine induced eating cannot, however, be caused by a local anaesthetic effect since a selective $\alpha$-sympatholytic drug phentolamine abolishes the eating response of clonidine.

The imidazolines are pure alpha-receptor activators as they lack beta-sympathomimetic activity (Mujic and van Rossum, 1965).

From studies on specific dopamine- and 5-hydroxytryptaminesensitive neurons of the snail brain, it is found that clonidine does not activate dopamine- or 5-hydroxytryptamine-receptors (Woodruff, unpublished data).

It may be concluded that clonidine acts on the hypothalamic eating system by activation of noradrenaline receptors which are analogous to the alpha-adrenergic receptors of the peripheral autonomic nervous system. 
168 [Broekkamp and v. Rossum: Clonidine Induced Intrahypothalamic Stimulation

Cardiovascular studies in our laboratory with intracerebral injection of clonidine provide evidence for a depressor effect of clonidine when injected in distinct areas of the hypothalamus (Struyker Boudier et al., 1972). These studies further substantiate the role of clonidine as an activator of brain noradrenaline receptors.

Following oral administration in patients with hypertension clonidine mainly exerts hypotensive effects. It may however be anticipated that in higher doses various behavioral effects might occur since noradrenaline plays an important role in various parts of the brain.

\section{References}

Boissier, J. R., Giudicelli, J. F., Fichelle, J., Schmitt, H., Mme. Schmitt, H.: Cardiovascular effects of 2-(2,6-dichlorophenylamino)-2-imidazoline (St 155). I. Peripheral sympathetic system. Europ. J. Pharmacol. 2, 333 (1968).

Hoefke, W., Kobinger, W.: Pharmacologische Wirkungen des 2(2,6-Dichlorphenylamino)-2-imidazolin-hydrochlorids, einer neuen antihypertensiven Substanz. Arzneimittel-Forsch. (Drug. Res.) 16, 1038-1050 (1966).

Kobinger, W.: ther den Wirkungsmechanismus einer neuen antihypertensiven Substanz mit Imidazolin-Struktur. Naunyn-Schmiedebergs Arch. Pharmak. exp. Path. 258, 48-58, 1967.

König, J. F. R., Klippel, R. A.: The rat brain. Baltimore: Williams and Wilkins 1963.

Mujic, M., van Rossum, J. M.: Comparative pharmacodynamics of sympathomimetic imidazolines; studies on intestinal smooth muscle of rabbit and the cardiovascular system of the cat. Arch. int. Pharmacodyn. 155, 432-449 (1965).

Schmitt, H., Mme. Schmitt, H.: Localization of the hypotensive effect of 2-(2,6dichlorophenylamino)-2-imidazoline-hydrochloride (St 155, Catapresan) in the medulla oblongata. Europ. J. Pharmacol. 6, 8-12 (1969).

- - Interactions between 2-(2,6-dichlorophenylamino)-2-imidazoline-hydrochloride (St 155, Catapresan ${ }^{\circledR}$ ) and $\alpha$-adrenergic blocking drugs. Europ. J. Pharmacol. 9, 7-13 (1970).

- - Fenard, S.: Evidence for an $\alpha$-sympathomimetic component in the effects of Catapresan on vasomotor centres: antagonism by piperoxane. Europ. J. Pharmacol. 14, 98-100 (1971).

Sherman, G. F., Greca, G. I., Woods, R. J., Buckley, J. R. : Evidence for a central hypotensive mechanism for 2-(2,6-Dichlorophenylamino)-2-imidazoline (Catapresan, St 155). Europ. J. Pharmacol. 2, 326-328 (1968).

Slangen, J. L.: Onderzoek over de identificatie van een centraal adrenergisch controlemechanisme voor de voedselopname van de rat. Diss., Universiteit van Utrecht, Drukkerij Bronder-Offset N.V., Rotterdam 1970.

- Miller, N. E.: Pharmacological tests for the function of hypothalamic norepinephrine in eating behavior. Phys. Behav. 4, 543-552 (1969).

C. Broekkamp

Department of Pharmacology

Catholic University Medical School

Nijmegen, The Netherlands 